\title{
THE USE OF INFORMATION AND COMMUNICATION TECHNOLOGY (ICT) IN ENGLISH TEACHING FOR ISLAMIC SENIOR HIGH SCHOOLS IN NGANJ UK
}

\author{
PENGGUNAAN TEKNOLOGI DAN KOMUNIKASI (TIK) DALAM PEMBELAJ ARAN \\ BAHASA INGGRIS PADA MADRASAH ALIYAH DI NGANJUK
}

\author{
Arjunina Maqbulin \\ M AN 2 Nganjuk \\ Arjunina.aa@gmail.com
}

\begin{abstract}
Recently, technology is a part of every ones' life, as well as the education. Right now, teachers should upgrade their ability in using the technology to improve their teaching. This research aimed at finding the answer of to what extend English teachers at Islamic senior high schools in Nganjuk have used Information and Communication Technology in their teaching, teachers' perception, and the problems they faced. The data were collected from English teachers who joined MGMP; a kind of English teachers' organization for English teachers professional development in Nganjuk. The research method used is qualitative. This research is a kind of survey design. Questionnaire was used to collect the data. Descriptive analysis was used to analyze the data. The result of this research revealed that majority of English teachers have used ICT in their teaching eventhough they did not use them optimally due to some problems, the data shows that $43 \%$ of the participants have used ICT, while $39 \%$ of them just sometimes use it, and $18 \%$ of them do not use it. The next finding is about teachers' perception. This research showed that teachers have good perception about the use of ICT, 73\% of the participants agreed that the use of ICT can make students more active in the classroom. The common problems they faced were the lack of facility and access, and lack of competence in using the technology. It is suggested that the school stakeholders evaluate the policy about the use of ICT in their schools. Then, English teachers' organization trough MGMP should be optimized to upgrade teachers' capability in using ICT for their teaching.
\end{abstract}

Key words: English Teachers, Islamic Senior High Schools, Information and Communication Technology.

\section{ABSTRAK}

Saat ini, teknologi menjadi bagian dari kehidupan setiap orang. Hal ini juga mempengaruhi dunia pendidikan. Para guru harus terus mengembangkan kemampuannya dalam penggunaan teknologi untuk memperbaiki kualitas pengajarannya. Penelitian ini bertujuan untuk menemukan jawaban seberapa banyak guru Bahasa Inggris di Madrasah Aliyah se Kabupaten Nganjuk telah menggunakan Teknologi Informasi dan Komunikasi dalam pengajarannya, persepsi guru, dan permasalahan yang mereka hadapi. Sasaran dalam penelitian ini adalah guru-guru bahasa Inggris tingkat MA se-kabupaten Nganjuk. Dalam penelitian ini data dikumpulkan dari guru bahasa Inggris yang mengikuti MGMP; sebuah organisasi guru bahasa Inggris untuk pengembangan profesional guru bahasa Inggris Madrasah Aliyah di Nganjuk. Metode penelitian yang digunakan adalah kualitatif. Desain dalam penelitian ini menggunakan survei. Kuesioner digunakan untuk mengumpulkan data, sementara analisis deskriptif digunakan untuk menganalisis data. Temuan penelitian ini mengungkapkan bahwa sebagian besar guru bahasa Inggris telah menggunakan TIK dalam pengajarannya meskipun mereka tidak menggunakannya secara optimal karena beberapa masalah. Data menunjukkan bahwa 43\% peserta telah menggunakan TIK, sedangkan 39\% diantaranya hanya kadang-kadang menggunakan TIK, sementara, $18 \%$ dari mereka tidak menggunakannya. Temuan selanjutnya adalah tentang persepsi guru. Hasil penelitian menunjukkan bahwa guru memiliki persepsi yang baik tentang penggunaan TIK, 73\% peserta setuju bahwa penggunaan TIK dapat membuat siswa lebih aktif di dalam kelas. Masalah umum yang mereka hadapi adalah kurangnya fasilitas dan akses, serta kurangnya kompetensi dalam menggunakan teknologi. Disarankan agar pembuat kebijakan di sekolah mengevaluasi kebijakan penggunaan TIK di sekolah mereka. Organisasi guru 
Bahasa Inggris atau MGMP seharusnya dapat dimaksimalkan agar dapat meningkatkan kemampuan guru dalam penggunaan ICT untuk kegiatan pembelajaran.

Kata Kunci : Guru Bahasa Inggris, Madrasah Aliyah, Teknologi Informasi dan Komunikasi.

\section{Introduction}

Recently, technology has become part of everyone's life. The use of technology cannot be separated from some one's life since people are facing Industrial Revolution (IR) 4.0 era now (Nordin, 2018; Zyad, 2016; Xu, 2018). It can be said that one of the central factors of IR 4 is the emphasis on the digital revolution. It refers to as the digital revolution due to the fact of the proliferation of computer systems and the automation of files in all fields (afrianto, 2018). It is the generation that manufacture is integrated beneath web control.

Moreover, why we should prepare our students in facing industrial revolution 4.0. This is because one task of education is preparing our students to face their world later (Marr, 2016; Shahroom, 2018). Today's teachers should be aware with the students' environtment. Students were born in the era that since they were kids, they are familiar with the technology. For example, teens who are very close to devices and or clever devices since they had been from babies. They are normally referred to as digital natives. While many teachers know devices and other units as digital immigrants. It is an undertaking for teachers to expect this situation in their studying process in the closeness of students with technology, such as gadgets, in the learning procedure in the classroom. Otherwise, our instructions will be boring (Afrianto, 2018).

Furthermore, teacher now should realize th at he or she is not the only source of knowledge. If students do not understand about the teacher explanation, they can easily find for the more detail explanation from internet. As it is now in their hands; mobile phone (Warni, 2018). The integration of internet with a phone as we know with android phone become a phenomena, because it is a tool that can be filled with many application, such as, social media, softwares, and hardwares (Wang and Woo, 2007). As this tool can be filled with many facilities, therefore, this tool can become an alternative for teacher to integrate the technology in teaching learning process (Ghavifekr, 2015; Ahmad, 2012; Suryani, 2010; Ammade, 2018) as almost all of students are having it right now. Some facilities that can be found in almost every mobile phone that can be used in teaching learning process is social media that is used in our daily life now, for example facebook (Rodliyah, 2016), edmodo (Okumura, 2016; Khongchan, 2013) and whatsapp (Susilo, 2014; Jafari, 2016; Alsaleem, 2014). That is why teacher should integrate their teaching learning process by using technology (Hazarika, 2007; Ahmad, 2012; Ghavifekr, 2015; Ammade, 2018). They can use internet, for example to teach, to guide, to train, to explain, to evaluate and to score. Beside that, another example of technology that can be integrated in teaching learning process are online dictionary, learning websites, email, you tube video, ipods, and ipads, smart board and laptop (Andrei, 2016; Hazarika, 2007).

However, in spite of the role of teacher in transfering knowledge that can be replaced by daring mode, virtual laboratory or robotics, the role of teacher in transferring knowledge, teaching the value, the norm, the culture, the experience, the wise, the empathy and the toleration can not be replaced by any kinds of technology (Supriano, 2018; Buza, 2017). Therefore, teachers will always be needed in teaching learning process, no matter how advanced the technology. Because the role of teacher is very important, it can be stated that teacher is the key in teaching learning process, because teacher is the one that is going to guide how to use the technology in teaching learning process and to help the students preparing their future (Ahmad, 2012; Buza, 2017; Anil, 2015).

For the reasons above, integrating technology in English class is a must, as some previous researchs have found that integrating the technology can improve the quality of teaching 
learning process (Buza, 2017; Eng, 2005; Ghavifekr, 2015; Ammade, 2018). Besides, it can improve the students' language learning skill because by using the technology they will be more motivated and interested wth the materials (Ahmadi, 2018; Warni, 2018). It shows that the use of technology in teaching learning process can grow the students confidence, improve their ability to communicate, make them get closer to their culture, make teaching more qualified, make students more comfort with the teacher and make the course mare flexible, as students can use the technology everytime and every where (Hazarika, 2017), it also develop students' thinking skill and make the activity in the class become students centered (Ahmadi, 2018) because students can learn actively during the lesson.

From the background of the research, the writer determines some purposes which become the aim of this research are:

- To find out how far the teachers in islamic senior high schools in Nganjuk integrate the ICT in the classroom.

- To find out teachers' perception on the use of ICT.

$\square$ To find out the problems faced by English teachers in integrating ICT in the classroom.

\section{REVIEW OF RELATED LITERATURE}

\section{A. Definition of ICT}

ICT is abbreviation of Information and Communication Technology. According to Perron, et al; 2010, they stated that ICTs are electronic tools that can be used to get, copy and save information. This tools is mostly influenced by internet. Another definition of ICT is as stated by Ajayi, 2009, that ICT can be defined as a technologycal tool as means of collecting (inputting/gathering), collating (processing/analyzing), and conveying (outputting/transferring) information through technology. Furthermore, this tool is very essential today, as information can be updated, kept and used as it is needed by using this tool. Not only for sharing information, but also affecting to the way people communicate today. In the last few years, people could communicate easily by using wire phone, or the phone was connected by using wire, therefore it could not be easily brought. However, nowadays, people can communicate with any people in the world by using ICT tool. Everything that happen in a part of a world can be easily seen by another people in another side of the world at the same time.

For more brief definiton about ICT is as stated by Selvan, et al. (2012), ICT or sometimes is synonimous term with Information Technology (IT), however for more common term, it is the integration of communication and telecommunication (telephone lines and wireless signals) computers, middleware as well as necessary software, storage- and audio-visual systems, which enable users to create, access, store, transmit, and manipulate information. From this definition it is clear that this tool has been functioned as a tool for communicating information. From those definitions we can conclude that ICT is an electronic tool that is used for making, accessing, manipulating and keeping the information. As its multiple function of this tool become a phenomenon today.

\section{B. The Importance of Integrating ICT in English Teaching}

The use of technology recently has become an urgent thing in teaching learning process, inside or outside the classroom (Ahmadi, 2018), this is in line with the result of research done by Ghavifekr and Rosdy (2015), the findings of their study indicate that teachers' well -equipped preparation with ICT tools and facilities is one the main factors in success of technology-based teaching and learning. Thus, the use of technology should be considered as a part of teaching learning process. Furthermore, Ahmadi (2018) stated that the use of technology provides interaction between teachers and learners, and a set of input and output. It also helps the students to improve their thinking skills, their confidence and their motivation to study a foreign language, and the class will be student centered.

Moreover, there are some effects in integrating the technology in Language teachinglearning in the classroom. According to Baytak, 
Tarman, and Ayas (2011), stated about the effects of technology in language learning. The result shows that the learners's acquisition is better when teachers use technology in the classroom. Students say that by using technology in the classroom, they feel more fun, and it also helps them to learn many things. Besides, technology makes learning more attractive and enjoyable. Another study about the use of tecnology also states that the use of technology will increase students' motivation, social interaction, coriousity and engagement.

Some studies about ICT integration also show that one of the effects of integrating technology in English class is that the increase of teachers and students cooperation. When teachers permit the students to become assistant in using the technology in teaching learning process, this will make students more confident. Students are given the opportunity to reinforce their opinions and abilities that they have. Students can help teachers in using the technology because they are better in mastering the technology while teachers focus on directing the instruction (Mouza, 2008).

\section{Kinds of ICT in English teaching}

Some alternative technologies that can be used in the classroom are computer, blogging, software, websites, facebook, edmodo, whatsapp, and you tube. By considering utilizing these technologies, teachers are hoped to get many benefits to improve teaching-learning process.

The first is computer, Becker (2000), states that computer is important instructional tool in language teaching. By using this technology, teachers will get good access when it is prepared well, besides teachers can have some freedom in curriculum. Today, ICT can be hardware such as computers, projectors, digital cameras, etc., and can also be software such as Microsoft Word, Power Point, etc. (Wang and Woo, 2007).

Another possibility is blogging. A blog can be created if teachers want to save pictures, material, worksheets, assignment, and notes for related topics. By using blog teacher can discuss the material anywhere, even outside of the classroom. Besides, students can upload their work in teacher's blog. Blog also can be used to test the students and score them too. students will get a chance to learn and relearn, discussing several topics and asking some questions without feeling ashamed. A research about blogging as part of ICT use in university was held by MuwangaZake, Parkes, \& Gregory (2010), their research suggested that university should make a blog that can support proffessional development in pedagogical use of ICT.

The next is using software, there are many softwares that can be chosen by teachers in their teaching, one of the example here is mindvisualizer. Mindvisualizer is a kind of emindmapping software that can be downloaded online. A study on it has been done by Salasiah (2017) who investigated the use of mindvisualizer in teaching writing in Parepare, Indonesia. In her study, she stated that there are a big contribution of mindvisualizer application in teaching writing. the students enjoy the process of teaching-learning by using this software because this software make them easier to improve their ideas in writing.

Another example of integrating the technology in the classroom is the use of facebook. The research about the use of facebook was done by Rodliyah (2016) who use Facebook closed group to enhance the writing of $E F L$ students in Bandung, Indonesia. The result of her study shows that by using facebook closed group the students can enhance their writing ability within four months,

Edmodo is also categorized as social media, but it is used specifically for education. It is a social networking site which is used to facilitate interaction between teacher and students. When teachers want to use Edmodo, they can register freely. A research about the use of Edmodo has been done by Okumura (2016), and Khongchan (2013). Their research is about Edmodo as a type of web 2.0 technology for teaching. Another research is done by Khongjan, he investigated the use of Edmodo and google docs in online classroom community in Thailand. His research shows that Edmodo and Google docs should be introduced first to the students before it is used. Moreover, Okumura, in his research 
about the use of Edmodo in language teaching in japanese university setting. His research shows the positive aspects of Edmodo. It shows that students develop their communication network with other students.

Furthermore, Susilo (2014), Jafari \& Chalak (2016) also conduct a research about using Whatsapp for teaching. Whatsapp is a mobile instant messaging application for smartphones. This application permits its user to send and accept messages, images, or video to others as long as they have internet connection. Jafari $\&$ Chalak (2016), for instance, focused their research on Whatsapp application as additional material for teaching vocabulary in English as foreign language classroom. Another study about the use of whatsapp in teaching process is done by Alsaleem (2014) about using WhatsApp applications to enhance students' writing, speaking, vocabulary and word choice in English dialogue journals. The result of this research shows that WhatsApp can enhance students writing, speaking, vocabulary and word choice ability. Because students can freely share their ideas.

Those are the kinds of ICT that can be alternatives to be used by teachers in the classroom. Based on the researches above, teacher should consider the use of technology that can be used to improve teaching learning process. The more references the teachers have, the more experiences they get to apply the use of technology in the subjects they handle.

\section{RESEARCH METHOD}

The method of this research is qualitative. This research is descriptive research by using survey design. The instrument used in this research is questionnaire. The questionnaire is proceeded by using googleform therefore this process can be done online.

The subjects of this research are Islamic Senior High School teachers in Nganjuk who join English Teachers Organization, which is named MGMP (Musyawarah Guru Mata Pelajaran). In fact, all teachers in Islamic Senior High Schools (34 Schools) have to join this organization as ruled by the religious ministry of Nganjuk district. However, some schools are reluctant to join due to the financial problem. So, there are 20 schools who join this organization, they are 3 state Islamic senior high schools and 17 private Islamic senior high schools. The data of this research were gathered by giving the questionnaire by using google form online for the members of MGMP, then the result of questionnaire is analyzed by using mean ad percentage.

\section{FINDING AND DISCUSSION \\ Finding}

\section{The Use of ICT in English Teaching}

The result of questionnaire shows about teacher and the use of ICT can be seen below.

Table 1; English teachers and the use of ICT

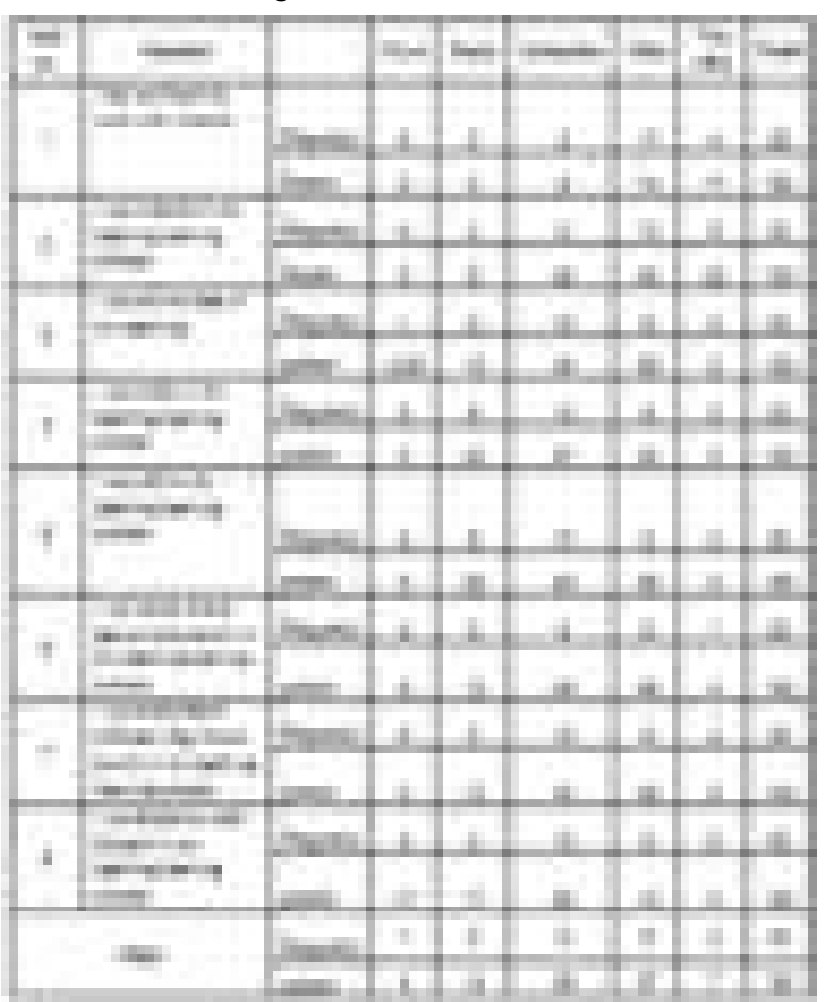

From the table above, it can be concluded that almost all teachers are familiar and have used internet, in item 1, $91 \%$ of participants are working with internet, and $65 \%$ using it in teaching learning process. This part shows that Islamic senior high school teachers in Nganjuk are using ICT in their work, especially internet. Beside internet, the kind of technology used is varies. The teachers who are often using presentation software are $44 \%$, such as power point tool (item 21). Besides $57 \%$ of 
them are sometimes using video in their teaching ( item 17). Furthermore, it can be concluded that teachers have used the technology in their teaching, and the kind of technology that they used are vary, however, internet is a kind that is mostly used by teachers. For the average use of ICT can be seen in the chart below;

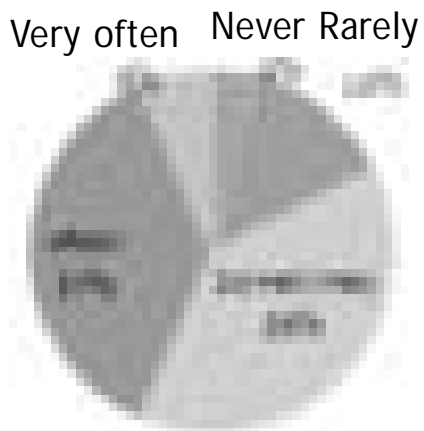

The average use of ICT by English teachers

The Chart above shows that teachers are using ICT in their teaching, whether they are often or just sometimes using it. So, it can be concluded that English teachers in Islamic Senior High Schools in Nganjuk have ever integrated ICT in their teaching as $43 \%$ of the participants often use ICT. However, there are $39 \%$ of the participants that sometimes use ICT. While the rest of them never integrate it. This fact shows that teachers have integrated ICT in their teaching but it is not optimal yet.

\section{Teachers Perception Towards the use of ICT}

The second variable of the questionnaire is teachers' perception on the use of ICT as educational tool or how the teachers think about ICT. The result of this part can be seen in the table below;

Table 2; Teachers' perception towards the use of ICT

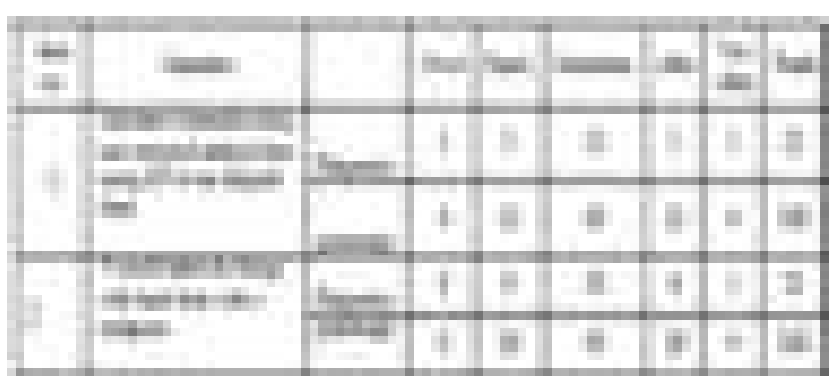

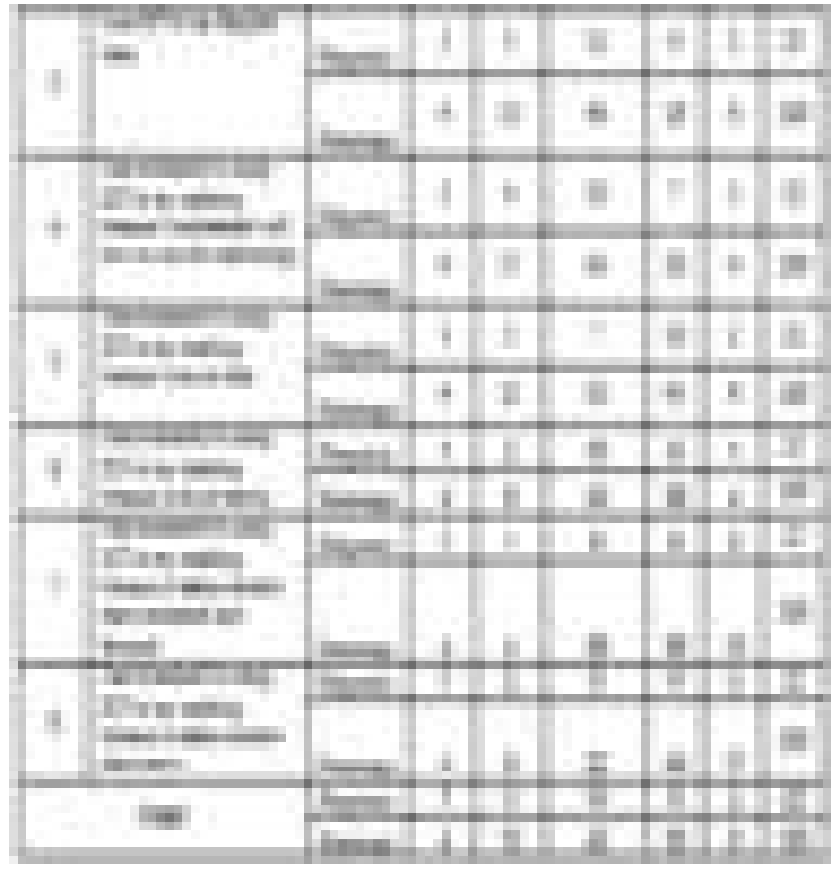

Over all, the teachers' perception on the use of ICT in teaching learning process is good. As we can see in item 3, $48 \%$ of the participants are sometimes using ICT in English teaching and $35 \%$ of them have integrated ICT in the classroom. As many of the participants choose sometimes, it means that teachers not always use of ICT in English teaching. However, when the reasons about why they use ICT, $52 \%$ of them agree that using ICT saves time, $43 \%$ say that it saves money too, $52 \%$ of them belief that ICT can make students become more interested and focused in their class, and $73 \%$ of them belief that the use of ICT can make students more active in their subject. Therefore, the teachers actually have good perception about integrating ICT in the classroom eventhough some of them do not integrate them yet in their teaching.

\section{Teachers Problem in Using ICT}

The fourth variable of the questionnaire is about the teachers problem in using ICT. The problems appear can be seen in the table below.

Table 3; Teachers' Problems in using ICT 


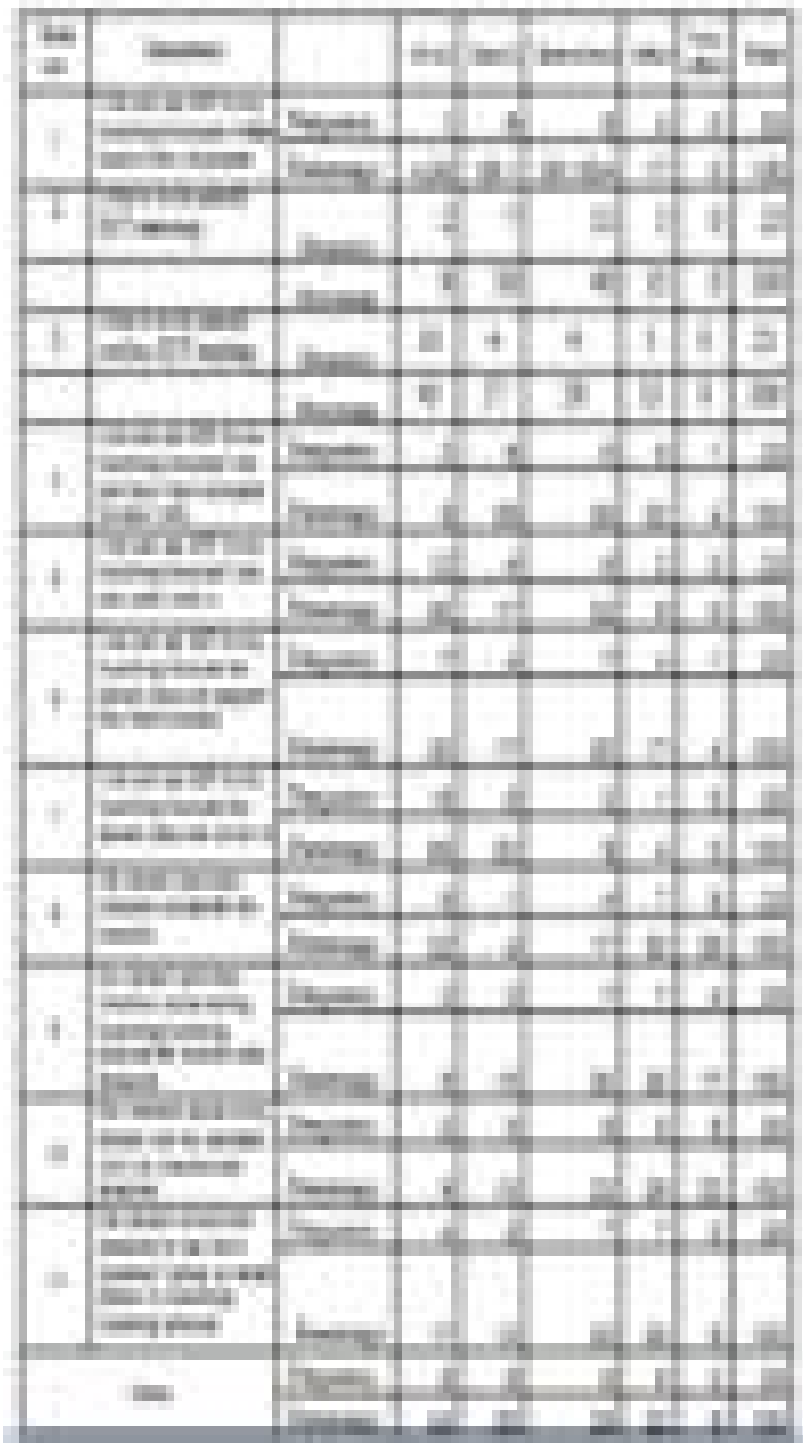

The result of the questionnaire dealing with the teachers problem about the use of ICT shows that some of problem faced by teachers about ICT is about the tool or acces, as stated in item 2, $26 \%$ of the participants do not have tool or acces to deal with ICT. However, overall, several Islamic Senior High Schools support the use of ICT for teaching, as can be seen that $56 \%$ of the schools provide internet acces for the teachers (item 8), $47 \%$ of the schools provides internet acces for teaching-learning process (item 9). Eventhough still there are some schools that still restrict the use of ICT, $21 \%$ of the participants' school do not support the use of ICT (item 6). And there is one school that does not allow the use of ICT in their school (item 7), then, $39 \%$ of the schools allow students to use ICT in the classroom, while $17 \%$, or 4 schools do not allow the students to use them (item 11).
The second problem is about lack of knowledge, only $13 \%$ percent of the participant that have ever joined ICT training, while $48 \%$ are sometimes join, this problem appear as not all of teachers have chances to join ICT training. Actually, there were many ICT training whether they were held by religious ministry or by another institution that could be followed, however, the follower are limited.

\section{Discussion}

\section{A. The Use of ICT in English Teaching}

Based on this research, English teachers of Islamic Senior High Schools in Nganjuk overall have ever used the technology, eventhough they do not use it in every of their teaching. it can be seen from the result of questionnaire that $65 \%$ of the participants are using internet for teaching, and $26 \%$ of them are sometimes using it, while $9 \%$ are rarely use it. This is in line with the research done by Hadijah (2007), she found that $58 \%$ of teachers in Pekanbaru had regularly integrated ICT during the teaching and learning activities, then $42 \%$ of them were sometimes use it as they stated that teacher did not always use the ICT as students need to use time of teaching learning process to practice and do exercise about the lesson. Therefore, it is clear that both English teachers in Islamic senior high schools in Nganjuk and English teachers in Pekanbaru do not always use ICT in their teaching, the use of ICT depends on the content of the syllabus. The similarities are both the content of the syllabus and some problems that probably encountered by teachers become the factors that influence the use of ICT by teachers (Habibu, 2012). However, there is diferent term appears here, the term of technology and term of Information and communication technology (ICT). ICT is a kind of technology that has specification in communicating the information (Selvan, 2012). As stated before that in Nganjuk there are 34 Islamic Senior High Schools that consist of 3 State Islamic Senior High Schools, and 31 Private Senior High Schools. There is a quite slight different about the ICT facilities in state and private schools. In state schools the ICT tools are much more used than the ICT tools in private 
schools. Therefore integrating ICT in teaching English is more possible to be conducted, as the word integrate means getting the meaning and presenting the information, for example by using digital means to synthesize, conclude, compare and contrast information from many resources (Katz, 2007). When using this definition, the term of integrating is related alot with the term ICT as ICT itself means a tool for communicating information (Ajayi, 2009). From those similarities, it can be concluded that the means that should be integrated in english teaching in 21st century is ICT tools (Ratheeswari, 2018). Eventhough ICT should be integrated in English teaching, in fact, many of english teachers in private islamic Senior High Scools get problems when trying to integrate ICT.

\section{B. Teachers Perception Towards the Use of ICT}

The result of this research shows that English teachers in Islamic Senior High Schools in Nganjuk have good perception on the use of ICT in their teaching. This is in line with the result of research of Karakaya (2010), his research found that English teachers have positive attitudes towards the use of computer. However, the case of the use of ICT in Turkey according to him, teachers have good perception about the use of ICT. This is in line with what happened to teachers in Nganjuk. The fact shows that eventhough teachers have good perception towards the use of ICT but they still feel reluctant to use it regularly in their teaching due to some the problems dealing with the facility and the competence.

\section{The Problems in Using ICT}

This research underlined some problems that revealed in integrating ICT in english class. The problems faced by English teachers in Nganjuk are still as the barriers that were reported by previous research they are the tools and access (Habibu, 2012), the school policy (Muslem, 2012), time management (Zyad, 2016) and teachers' professional development dealing with ICT (Bingimlas, 2009).

The first is about the tools and access, for example computer that can be used by students is limited. This is as stated by Suryani (2010) that one of the problem faced by teachers in integrating ICT is lack of computer facilities. This problem is not only happen in Nganjuk, but also in a big city such as Pekanbaru, Riau (Hadijah, 2017). In this research the common tools used in teaching are the tools used to support listening section activity such as speaker and laptop or computer. Besides, another teaching tool that is prepared in every schools is LCD. However, in fact teacher can not use it easily as its number is limited, therefore, when teacher wants to use it she or he has to ensure that the other teacher do not use it. Those two tools are the only tools that are commonly found every school with limited number. While the tools used to support the integrating of ICT in teaching like smartphone, computer or laptop with internet access were hard to find. That is why this problem make teacher to be reluctant to integrate ICT in their teaching eventhough they have positive perception about the use of ICT.

The second problem is about teachers lack of knowledge. Some teachers admit that they are competent enough in using the technology, however, the technology used deals with the administrative matter, for example doing the students report book, updating official matter, and writing about staffing report. They acquire in operating computer dealing with that matter well, but when the ICT needed for teaching some teachers are still feel reluctant. Just a simple thing for turning on a $L C D$, sometimes some teachers still have problem when turning on LCD. Therefore it is important that teachers join a training about managing ICT for teaching, as the result of this research showed that $39 \%$ of the participants never join any kinds of ICT training. Teachers need to learn more about ICT as Dlamini (2018) recommended that teacher learning is as important as learners learning. The minimum training about ICT held should be responded by teachers by maximazing their work group, such as MGMP (Musyawarah Guru Mata Pelajaran).

In Nganjuk, this group is legally formed by religious ministry of Nganjuk District in 2010. some activities that can be done in this MGMP is sharing ICT teaching experience. The regular 
meeting of this work group is done six time every semester. The activity done commonly are arranging lesson plan, sharing teaching experience, learning together (Holding a workshop or seminar), and making final test questions. This activity is a place where teachers can improve their professional development as it was also found that professional development training programs for teachers also played a key role in enhancing students' quality learning (Ghavifekr, 2015).

Teacher professional development through MGMP can become an alternative to improve teachers capability in integrating ICT in English teaching. As stated by Avalos (2011), teachers continue to be both the subjects and objects of learning, it means that teacher is not only the one who should teach or share their knowledge as a subject of learning, but he or she should also keep on learning because he or she is always be the object of learning. Therefore, it is important for teachers to upgrade thair capability in integrating ICT in English teaching as it can improve learners' learning process, that is why teachers need to be supported and trained for integrating teachnology into language teaching (Ahmadi, 2018).

Furthermore, as stated by Darling (2017) that a good design of professional development should become an important component of a comprehensive system of teaching and learning that supports students to develop the knowledge, skills, and competencies to face the 21st century. While one of important skill and competencies in the 21st century in facing the fourth Industrial Revolution is the use of technology that plays important role as it impacts all aspects of our society, including education. With the assistance of technology, educational innovation and creations are constantly being produced thus leading to more enhanced and advanced educational ecosystems (Nordin, 2015). So, integrating ICT in English teaching is a part of educational system to prepare our students for their future and to survive in the fourth industrial revolution (Nordin, 2018).

Within years the design of MGMP meeting in Nganjuk is held six times in a semester. With the main topic discussed is about designing lesson plan and preparing questions for final semester test. On the other hand, it does not discuss about how to improve teachers ability especially about the use of ICT yet. Therefore, it is suggested that the design of MGMP meeting for English teachers of Islamic Senior High Schools in Nganjuk should include ICT as a topic of discussion. This is needed as the result of this research showed that teachers ability in integrating ICT in their teaching need to be improved, it means that their competency in using ICT for teaching need to be up grading. By adding ICT as a material of discusson in MGMP, teachers can improve their ability in using ICT for teaching. Teachers can share experience or plan to have workshop about integrating ICT in teaching in MGMP program. Therefore it can be concluded that joining MGMP can become an alternative to solve teachers problem dealing with the minimum knowledge about integrating ICT for teaching English.

\section{CLOSING}

\section{A. Conclusion}

The result of this research shows that English teachers of Islamic Senior High Schools in Nganjuk have used ICT but they do not use the ICT optimally yet, eventhough actually they have good perception about the use of ICT. this is due to the problems that the teachers face. While in integrating ICT teachers face many problems such as lack of knowledge, lack of support and lack of time to prepare. To cope those problems teachers profesional development is needed

Teachers professional development about integrating ICT in English class still need to be improved, as $39 \%$ of the participants learn about ICT by themselves, it means that teacher professional development that discuss about the use of ICT in English teaching is very rarely held or almost never be conducted. In addition teachers have good perception about the use of ICT. Furthermore, the ICT tools that are often used by teachers is internet, however the ICT that they use mostly for administrative matter. Teachers are mostly able to operate ICT when it deals with administrative matter such as doing 
students digital report book (ARD; aplikasi rapot digital) and fill in Simpatika (teachers data).

\section{B. Suggestion}

As the result of this study shows that teachers do not integrate ICT optimally in their teaching due to some problems, a further study about the way how to improve teachers will to use ICT in their teaching is a possible to be conducted. This study also imply that the school stake holder and the policy maker should think again about the policy that have been made. The facility of technology is needed to be improved so that teachers can use it well. $[\alpha]$

\section{REFERENCES}

Afrianto. 2018. "Being a Professional Teacher in the Era of Industrial Revolution 4.0: Opportunities, Challenges and Strategies for Innovative Classroom Practices". ELTARISSN 2614-1108.

Ahmad, J. 2012. "English Language Teaching (ELT) and Integration of Media Technology". Procedia - Social and Behavioral Sciences 47 ( 2012 ) 924 - 929.

Ahmadi, M., R. 2018. "The use of technology in english language learning: A literature review". International Journal of Research in English Education, Volume 3, Number 2, p 115-126.

AJAYI, 0. 0. 2009. "E-learning: A Shorter, Safer, and Surer Route to Reaching the Education For All Destination”. J ournal of Science and Technical Education (JSTE), Akungba. ISSN: 978-978-49161-9-6, Vol.1, No.1, pgs. 138-145

Alsaleem, B. I. A. 2014. "The effect of "WhatsApp" electronic dialogue journaling on improving writing vocabulary word choice and voice of EFL undergraduate Saudi Students". Harvard: 21st Century Academic Forum Conference Proceedings. http:/ / www. readwritethink.org/lesson images/ lesson 782/ Rubric.pdf

Ammade, S., Mahmud, M., Jabu, B., \& Tahmir, S. 2018. "Integrating Technology in English Language Teaching: Global Experiences and Lessons for Indonesia". International Journal of English Linguistics; Vol. 8, No. 6; ISSN 1923-869X E-ISSN 1923-8703 Published by Canadian Center of Science and Education .

Andrei, E. 2016. "Technology in Teaching English Language Learners: the Case of Three Middle School Teachers". TESOL J ournal.

Anil, B. 2015. "Use of Technology in English Teaching Classroom-A Study". American International Journal of Research in Humanities, Arts and Social Sciences, 9(4), pp. 316-318.

Avalos, Beatrice. 2011. "Review Teacher Professional Development in Teaching and Teacher Education Over Ten Years". Teaching and Teacher Education 27 (2011) 10-20, journal homepage: www.elsevier.com/ locate/ tate

Baytak, A., Tarman, B., \& Ayas, C. 2011. "Experiencing technology integration in education: children's perceptions". International Electronic J ournal of Elementary Education, 3(2), 139-151.

Becker, H. J. 2000. "Findings from the teaching, learning, and computing survey: Is Larry Cuban right"? Education Policy Analysis Archives, 8(51). doi: http:/ / dx. doi.org/ 10.14507/ epaa.v8n51.2000

Bingimlas, K., A. 2009. "Barriers to the Successful Integration of ICT in Teaching and Learning Environments: A Review of the Literature". Eurasia J ournal of Mathematics, Science $\&$ Technology Education, 5(3), 235-245.

Buza, K., \& Mula, M. 2017. "The role of the Teachers in the integration of ICT in Teaching in Secondary Low Education”. European J ournal of Social Sciences Education and Research, ISSN 2411-9563 (Print) ISSN 2312-8429 (Online)

Darling-Hammond, L., Hyler, M. E., Gardner, M. 2017. Effective Teacher Professional Development. Palo Alto, CA: Learning Policy Institute.

Eng, T.S. 2005. "The Impact of ICT on Learning: A Review of Research". International Education Journal, 6(5), 635-650. ISSN 1443-1475. 
Ghavifekr, S. \& Rosdy, W.A.W. 2015. "Teaching and learning with technology: Effectiveness of ICT integration in schools". International J ournal of Research in Educationand Science (IJ RES), 1(2), 175-191.

Habibu, T, . Al-Makmun, A, \& Clement, C. 2012. "Difficulties Faced by Teachers in Using ICT in TeachingLearning at Technical and Higher Educational Institutions of Uganda". International Journal of Engineering Research \& Technology (IJ ERT) Vol. 1 Issue 7, ISSN: 2278-0181.

Hadijah, S, \& \& shalawati. 2017. "Investigating Teachers' Barriers to ICT (Information Communication Technology Integration in Teaching English at Senior High Schools in Pekanbaru". Proceedings of the Fifth International Seminar on English Language and Teaching (ISELT-5) P-ISSN: 2580-1287. P-ISSN: 2597-6346.

Hazarika, Z. 2017. "Exploring the Impact of Technology in Teaching English: Tesol in the Context". European J ournal of English Language and Literature Studies Vol.5, No.10, pp.19-28.

Jafari, S. , \& Chalak, A. 2016. "The Role of WhatsApp in Teaching Vocabulary to Iranian EFL Learners at J unior High School". English Language Teaching, 9(8), 85. https:/ / dx. doi.org/ 10.5539/ elt.v9n8p85

Karakaya, Kadir. 2010. "An Investigation of English Language Teachers' Attitudes towards Computer Technology and Their Use of Technology in Language Instruction". Published Thesis, Lowa State University, https:/ / www.researchgate. net/ publication/ 329251147

Katz, I.R; Macklin, A, S. 2007. "Information and Communication Technology (ICT) Literacy: Integration andAssessment in higher Education". Systemics Cybernetics and Informatics Volume 5-Number 4, P. $50-55$

Kongchan, C. 2013. "How Edmodo and Google Docs can change traditional classrooms". In The European Conference on Language Learning 2013. Retrievedfrom ht tp:/ / iafor.info/ archives/ offprints/ ecll2013-oifprints / ECLL2013_0442.pdf

Kottner, J. \& Streiner, D.L. (2010). Internal consistency and Cronbach?s alpha: A comment on Beeckman et al. (2010). International Journal of Nursing Studies, 47(7), 926-928.

Marr Bernard. 2016. "why everyone must get ready for 4th industrial Revolution". https:// www.forbes.com.

Mouza, C. 2008. "Learning with laptops: Implementation and outcomes in an urban, underprivileged school". Journal of Research on Technology in Education, 40(4), 447-472. https:/ / eric.ed.gov/ ?id=E] 826086

Muslem Asnawi, Q.Y. Yunisrina, Juliana Rena. 2018. "Perceptions and Barriers to ICT use among English teachers in Indonesia". Teaching English with Technology, 18(1), 3-23, http:/ / www. tewtjournal.org

Muwanga-Zake, J. W., Parkes, M., \& Gregory, S. 2010. "Blogging at university as a case study in instructional design: Challenges and suggestions towards professional development". International Journal of Education and Development using Information and Communication Technology, 6 (1), 14-29. Retrieved from http:/ / ijedict.dec.uwi.edu/ viewarticle. php?id=796

Nordin, N., Norman, H., Din, R., Ally, M., \& Dogan, H. 2015. "Exploring the roles of social participation in mobile social media learning: A social network analysis". The International Review of Research in Open and Distributed Learning, 16(4).

Nordin, N., \& Norman, H. 2018. "Mapping The Fourth Industrial Revolution Global Transformations on 21 Century Education on the Context of Sustainable Development". Journal of Sustainable Development Education and Research | JSDER Vol. 2, No.1, pp. 1-7

Okumura, S. 2016. "The use of an educational social networking site for English language learning beyond the classroom in a Japanese university setting". Retrieved from https:/ / mukogawafrom.repo.nii.ac. jp/ ? action=repository_action_common_download\&item_id=686\&item_n $0=1 \&$ attribute_id $=22 \&$ file_no $=1$

Perron, Taylor, Glass, Margerum-Leys. 2010. "Information and Communication Technologies in Social Work". Vol. 11 No. 1 (Spring 2010), 67-81

Ratheeswari, K. 2018. "Information Communication Technology in Education". Journal of Applied and Advanced Research, 2018: 3(Suppl. 1) S45?S47; Phoenix Research Publishers

Rodliyah, R. S. 2016. "Using Facebook Closed Group to Improve EFL Students' Writing". TEFLIN J ournal, 
27(1), 82-100.

Salasiah, A. 2017. "Using Mindvisualizer as Digital Brainstorming in Teaching Writing: A Study at Muhammadiyah University of Parepare". Retrieved from http:// asian-efl-journal.com/ wp-content/ uploads/AEJ-Special-Edition-December-2016-TESOL-Indonesia-Conference-Volume-9.pdf

Selvan, T., Sivakumar, Sevukan, R. 2012. "Information and Communication Technology". International J ournal of Library and Information Science (IJ LIS), Volume 1, Issue 1, January- April (2012), pp. 15-28, () IAEME: www.iaeme.com/ ijlis. html.

Shahroom, A., A., \& Hussin, N. 2018. "Industrial Revolution 4.0 and Education". International J ournal of Academic Research in Business and Social Sciences, Vol. 8, No. 9, Pg. 314 - 319.

Supriano. 2018. "Di Era Revolusi Industri 4.0, Peran Guru Tak Guru Tak Tergantikan, Tapi..". https:// edukasi. kompas.com/ read/ 2018/11/28/17550091/ di-era-revolusi-industri-40-peran-gurutak-tergantikan-tapi.

Suryani, A. 2010. "Ict in Education: Its Benefits, Difficulties, and Organizational Development Issues". jsh Jurnal Sosial Humaniora, Vol 3 No.1, p.106-124.

Susilo, A. 2014. "Exploring Facebook and Whatsapp as Supporting Social Network Applications for English Learning in Higher Education". Retrieved from http:/ / repository.ut.ac.id/4930/ 1

Wang, Q., \& Woo, H. L. 2007. "Systematic planning for ICT integration in topic learning". Educational Technology \& Society, 10(1), 148-156.

Warni, S., Aziz, T.A., \& Febriawan, D. 2018. "The Use of Technology in English as a Foreign Language Learning Outside the Classroom: an Insight into Learner Autonomy". LLTJ ournal, e-ISSN 2579-9533, p-ISSN 1410-7201, Vol. 21, No. 2, October 2018, DOl: doi.org/ 10.24071/ Itt.2018.210203

Xu, M., David, J., \& Kim, S. 2018. "The Fourth Industrial Revolution: Opportunities and Challenges". International J ournal of Financial Research, Vol. 9, No. 2.

Zyad, H. 2016. "Integrating Computers in the Classroom: Barriers andTeachers Attitude". International Journal of Instruction Vol.9, No.1e-ISSN: 1308-1470 p-ISSN: 1694-609X. www.e-iji.net 